\title{
PENDIDIKAN, KESEHATAN DAN PERTUMBUHAN EKONOMI REGIONAL DI INDONESIA: PENDEKATAN MODEL PANEL DINAMIS
}

\author{
Aminuddin Anwar \\ Fakultas Ekonomi Universitas Islam Indonesia \\ Ring Road Utara, Condongcatur, Depok, Sleman, Yogyakarta 55283, Indonesia. \\ E-mail Korespondensi: aminuddin.anwar@uii.ac.id
}

\begin{abstract}
This study analyzes the contribution of human capital ie education and health to regional economic growth in Indonesia. This study uses the regional level of the province as the unit of analysis with the timeframe from 2004 to 2014. Development of economic growth model which is a dynamic model becomes a challenge for estimation of regression model, this study uses generalized method of moment (GMM) as an analytical tool to overcome bias Which occurred on the model of economic growth. This study provides empirical evidence on the role of education and health to regional economic growth in Indonesia. In addition, the estimation results also provide empirical results of conditional convergence with the contribution of human capital that is education and health as a determinant of convergence
\end{abstract}

Key Words: education, health, economic growth, dynamic panel data

JEL Classification: I25, I15, O47, C33

\section{PENDAHULUAN}

Pertumbuhan ekonomi yang berkelanjutan menjadi salah satu tujuan utama dalam proses pembangunan ekonomi. Capaian pertumbuhan ekonomi yang berkelanjutan tersebut dapat dicapai dengan meningkatkan sumber utama pertumbuhan ekonomi yang memiliki implikasi akumulatif. Salah satu sumber utama tersebut adalah modal manusia. Modal manusia menjadi salah satu bagian penting dalam pembangunan perekonomian suatu negara karena ketika memiliki modal manusia yang berkualitas akan memberikan kontribusi lebih besar bagi pembangunan ekonominya. Secara teoritis menurut (Schultz, 1961) modal manusia dapat dimaknai sebagai suatu konsep angkatan kerja dalam perspektif klasik mirip dengan suatu properti dan dikonseptualisasikan sebagai kapasitas produktif dari manusia yang jauh lebih besar dibandingkan dari semua kekayaan yang dimiliki bersama.
Konsep modal manusia memainkan peran utama dalam teori pertumbuhan ekonomi modern. Pada tingkat ekonomi makro stok modal manusia memiliki peran penting bagi proses pertumbuhan ekonomi, pada tingkat mikro modal manusia dapat menjelaskan variasi dalam struktur upah dan distribusi upah antar individu dan kelompok. Lebih lanjut modal manusia menurut (Becker, 2006) didefinisikan sebagai pengetahuan, informasi, ide, keahlian dan kesehatan dari seorang individu. Menurut (Hanushek, 2013) kualitas tenaga kerja memiliki hubungan yang konsisten, stabil, dan kuat terhadap pertumbuhan ekonomi tetapi hubungan pertumbuhan ekonomi tidak muncul sebagai hasil dari kualitas yang lebih tinggi melalui investasi sumber daya di sekolah-sekolah. Hal utama yang menjadi penting bagi negara-negara berkembang ini adalah investasi mereka dalam pendidikan dasar dan menengah (Becker, 2006).

Teori dasar dari model pertumbuhan endogen adalah fokus pada adanya peran dari modal 
manusia yang dipelopori oleh (Lucas, 1988) dan (Romer, 1990). Menurut (Lucas, 1988) gagasan modal manusia tidak hanya memberikan efek internal tetapi memberikan efek lanjutan yaitu efek eksternal yang terlihat dari kondisi analisis agregat. Menurut (Bloom, Canning, \& Sevilla, 2004) salah satu kritik dalam aplikasi model pertumbuhan ekonomi adalah tidak mempertimbangkan kesehatan sebagai bagian dalam model pertumbuhan ekonomi. Lebih lanjut dijelaskan oleh (Bloom et al., 2004) pekerja yang sehat secara fisik dan mental akan berpengaruh secara multidimesional sehingga akan meningkatkan produktifitasnya dan mendapatkan pendapatan yang lebih tinggi. Jalur dari adanya kualitas pendidikan dan kesehatan adalah kemampuan dan keterampilan yang akan meningkatkan kapasitas untuk berproduksi selanjutnya mengembangkan kapasitas diri dalam meningkatkan kapasitas ekonomi suatu negara. Ukuran keberhasilan investasi pada bidang pendidikan dan kesehatan dapat ditunjukkan pada hasil produktivitas yang dihasilkan oleh individu. Menurut (Hanushek \& Kimko, 2000), tingkat pertumbuhan ekonomi dipengaruhi oleh gagasan dan penemuan, yang terkait dengan persediaan modal manusia baik melalui kegiatan penelitian dan pengembangan (R\&D) atau melalui perilaku adopsi.

Perkembangan penelitian tentang pendidikan dan kesehatan terhadap pertumbuhan ekonomi telah banyak dilakukan sebelumnya. Perkembangan tersebut meliputi pengembangan model, variabel dan alat analisis yang berbeda. Penelitian awal yang berfokus pada pendidikan dilakukan oleh (Mankiw, Romer, \& Weil, 1992) menggunakan augmented solow growth model dengan modal manusia sebagai faktor produksi tambahan sementara itu dengan menerapkan model pertumbuhan endogen (Lucas, 1988); (Romer, 1990) juga menghubungkan modal manusia dan adopsi teknologi sebagai faktor penting dalam meningkatkan pertumbuhan. Se- mentara itu, (Benhabib \& Spiegel, 1994) misalnya telah menemukan adanya hubungan yang lemah antara pertumbuhan dan peningkatan sumber daya manusia diukur dalam hal pencapaian pendidikan. Sementara itu penelitian dari (Pritchett, 2001), menjelaskan bahwa terjadi variasi yang berbeda mengenai dampak pendidikan terhadap pertumbuhan ekonomi hal tersebut dikarenakan lingkungan institusi, penawaran pekerja berpendidikan meningkat tetapi permintaan cenderung tetap, dan terjadi perbedaan kualitas pendidikan.

Kontribusi dari kesehatan terhadap pertumbuhan ekonomi ditunjukkan oleh beberapa penelitian seperti (Aka \& Dumon, 2008) bukti empiris menunjukkan bahwa dinamika jangka panjang dari proses pertumbuhan dijelaskan oleh kesehatan masa lalu dan tingkat pendidikan. Kontribusi dari (Bloom et al., 2004) hasil utama kami adalah bahwa kesehatan yang baik memiliki efek positif, cukup besar, dan secara statistik signifikan pada output agregat. Studi yang dilakukan (Barro, 2013) menggunakan data antar negara menemukan bukti hubungan parsial antara pertumbuhan dan harapan hidup dimana ditunjukkan bahwa antara status kesehatan dan pertumbuhan ekonomi adalah positif. Studi lain dari (Knowles \& Owen, 1995) menggunakan data antar negara menunjukkan hubungan yang lebih kuat antara pendapatan per kapita dan modal kesehatan, dan pendapatan per kapita terahadap modal pendidikan. Pada level daerah studi (Li \& Huang, 2009) antar daerah di China menggunakan panel statis pada provinsi di China menemukan efek positif dari pendidikan dan kesehatan terhadap pertumbuhan ekonomi di China untuk periode 1978-2005. (Li \& Liang, 2010) antar negara di Asia Timur yang menemukan bahwa peran dari pendidikan dan kesehatan secara positif berpengaruh terhadap pertumbuhan ekonomi, tetapi peran dari kesehatan memiliki kontribusi yang lebih besar. 
Perkembangan yang cukup signifikan ditunjukkan tidak hanya secara hasil empiris tentang studi pertumbuhan ekonomi. Beberapa perkembangan lanjutan memberikan kontribusi berupa metode estimasi yang berbeda. Penelitian awal tentang modal manusia dan pertumbuhan ekonomi menggunakan data cross section dan metode ordinary least square yaitu (Mankiw et al., 1992) dan (Benhabib \& Spiegel, 1994). Perkembangan lanjutan ditunjukkan oleh (Aka \& Dumon, 2008) dengan metode time series, sementara itu model lanjutan yang digunakan beberapa penelitian selanjutnya adalah panel statis yaitu (Barro, 1992), dan (Barro, 2013). Model dengan prinsip estimasi lanjutan yang merupakan model data panel dengan kondisi dinamis yaitu (Knowles \& Owen, 1995), (Islam, 1995), (Caselli, Esquivel, \& Lefort, 1996), (Bond, Hoeffler, \& Temple, 2001), (Li \& Huang, 2009) dan (Li \& Liang, 2010).

Penelitian di Indonesia secara aplikatif menggunakan model dinamis pertumbuhan ekonomi sebagai model acuan untuk menganalisis konvergensi di Indonesia yaitu (Firdaus \& Yusop, 2009) pada level provinsi dan periode 1983-2003 dengan menggunakan metode General Method of Moments (GMM). Penelitian
(Kharisma \& Saleh, 2013), menganalisis dispersi pendapatan serta menguji konvergensi absolute (absolute convergence) serta conditional convergence di 26 provinsi di Indonesia selama periode 1984-2008 dengan model panel dinamis. Penelitian ini secara spesifik melakukan analisis dalam konteks model dinamis dengan data panel untuk aplikasi regional provinsi di Indonesia. Penelitian ini mencoba memberikan analisis secara empiris kontribusi komposisi dari modal manusia yaitu pendidikan dan kesehatan terhadap pertumbuhan ekonomi di Indonesia.

\section{METODE PENELITIAN}

Penelitian ini menggunakan data panel yang merupakan gabungan dari cross section dan time series untuk level provinsi di Indonesia. Data yang digunakan yaitu pada 33 provinsi di Indonesia pada periode antara 2004 sampai 2014. Secara umum penelitian empiris ini menggunakan data sekunder yang diambil dari Badan Pusat Statistika. Penelitian ini menggunakan variabel pertumbuhan ekonomi, indikator pendidikan, kesehatan, investasi dan pengeluaran pemerintah. Definisi secara lebih jelas variabel-variabel tersebut dapat dijelaskan sebagai berikut:

Tabel 1

Definisi Operasional Variabel

\begin{tabular}{l|c|c|l}
\hline \multicolumn{1}{c|}{ Variabel } & Lambang & Satuan & \multicolumn{1}{c}{ Keterangan } \\
\hline Pertumbuhan ekonomi & $\Delta y_{i t}$ & Juta Rupiah & $\begin{array}{l}\text { Nilai pertumbuhan PDRB per Kapita an- } \\
\text { tara periode } t-1 \text { dan } t\end{array}$ \\
\hline $\begin{array}{l}\text { Nilai Output per } \\
\text { Kapita }\end{array}$ & $y_{i t}$ & Juta Rupiah & Nilai PDRB per Kapita riil. \\
\hline $\begin{array}{l}\text { Rasio Investasi ter- } \\
\text { hadap PDRB per } \\
\text { Kapita }\end{array}$ & $s_{k i t}$ & Milyar Rupiah & $\begin{array}{l}\text { Total investasi (Penanaman Modal Asing } \\
\text { (PMA) dan Penanaman Modal Dalam } \\
\text { Negeri (PMDN)) per PDRB per Kapita }\end{array}$ \\
\hline $\begin{array}{l}\text { Pendidikan } \\
\text { Kesehatan }\end{array}$ & $e_{i t}$ & Tahun & $\begin{array}{l}\text { Rata-rata lama sekolah penduduk usia 15 } \\
\text { tahun keatas. }\end{array}$ \\
\hline
\end{tabular}




\begin{tabular}{l|c|c|l}
\hline \multicolumn{1}{c|}{ Variabel } & Lambang & Satuan & \multicolumn{1}{c}{ Keterangan } \\
\hline $\begin{array}{l}\text { Rasio pertumbuhan } \\
\text { penduduk dan tingkat } \\
\text { tabungan. }\end{array}$ & $n_{i}+g+\delta$ & Rasio & $\begin{array}{l}\text { Rasio pertumbuhan penduduk dan ting- } \\
\text { kat tabungan (diasumsikan nilai } g+\delta \\
\text { adalah 0.05) }\end{array}$ \\
\hline $\begin{array}{l}\text { Pengeluaran } \\
\text { pemerintah }\end{array}$ & $g x_{i t}$ & Milyar Rupiah & $\begin{array}{l}\text { Nilai total pengeluaran pemerintah per } \\
\text { PDRB per Kapita }\end{array}$ \\
\hline
\end{tabular}

Sumber: Penulis

Secara teoritis penelitian ini mengadopsi model Augmented Solow Growth Model yang dilakukan oleh (Mankiw et al., 1992) yang dikembangkan oleh (Knowles \& Owen, 1995) dan (Li \& Liang, 2010) dengan menambahkan modal manusia dalam bentuk pendidikan dan kesehatan pada konteks data panel. Model tersebut adalah sebagai berikut:

$$
\begin{aligned}
\ln y_{i t}=\eta_{i} \ln y_{i, t} & +\beta_{i 1} \ln s_{k i t}+\beta_{i 2} \ln e_{i t} \\
& +\beta_{i 3} \ln h_{i t}+\beta_{i 4} \ln \left(n_{i}+g+\delta\right)_{i t} \\
& +\beta_{i 5} \ln g x_{i t}+\mu_{i}+\varphi_{t}+\varepsilon_{i t}
\end{aligned}
$$

Dimana nilai $\ln y_{i t}$ adalah nilai adalah nilai $\log$ output perkapita $\ln y_{i, t-\tau}$ adalah nilai kondisi awal $\log$ output perkapita, $\ln s_{k i t}, \ln e_{i t}, \ln h_{i t}$, dan $\ln \left(n_{i}+g+\delta\right)_{i t}$ dan $d f_{i t}$ adalah nilai log dari stok modal fisik per kapita, log dari pendidikan, log kesehatan dan rasio tabungan dan pertumbuhan penduduk dan desentralisasi fiskal. Nilai $\eta_{i}$ merupakan indikator dari konvergensi beta, $\beta_{i 1}$, $\beta_{i 2}, \beta_{i 3}, \beta_{i 4}$ dan $\beta_{i 5}$ merupakan nilai koefisien parameter estimasi untuk variabel modal fisik per kapita, log dari pendidikan, log kesehatan dan rasio tabungan dan pertumbuhan penduduk, dan pengeluaran pemerintah. Nilai $\mu_{i}, \varphi_{t}$ dan $\varepsilon_{i t}$ merupakan nilai efek spesifik daerah, efek spesifik waktu dan nilai eror pada daerah $i$ dan waktu $t$.

Metode estimasi yang digunakan dalam penelitian ini adalah Generalized Method of Moments (GMM). Metode estimasi ini digunakan karena beberapa alasan utama yang muncul dalam melakukan estimasi. Penggunaan metode regresi cross-section dalam model pertumbuhan (crosssection growth regression) dikritik oleh (Ross \&
Renelt, 1992) karena metode ini sangat sensitif terhadap variabel independen yang diikutsertakan dalam spesifikasi atau dengan kata lain parameter yang diestimasi nilainya berubah sangat signifikan ketika satu atau lebih variabel dimasukkan atau dikeluarkan dari dalam model. Hal tersebut menunjukkan kemungkinan model terkena masalah omitted variabel bias. Menurut (Caselli et al., 1996) terdapat dua sumber dari inkonsistennya dalam penelitian empiris pertumbuhan ekonomi antar negara. Pertama, perlakuan yang tidak tepat pada efek spesifik pada negara yang merepresentasikan perbedaan dalam hal teknologi atau selera sehingga memberikan kenaikaan pada bias adanya ommited variabel. Adanya hal tersebut diasumsikan bahwa efek ommited variabel yang terjadi tidak berkorelasi dengan variabel yang berada di sebelah kanan persamaan, tetapi asumsi ini tentu melanggar karena sifat dinamis dari regresi pertumbuhan. Kedua, terdapat argumen teoritis yang kuat bahwa setidaknya subset dari variabel penjelas harus diharapkan endogen. Meskipun masalah ini umumnya diakui dalam literatur, beberapa upaya untuk mengendalikan hal ini telah dibuat.

Ada dua estimasi GMM yang umum digunakan untuk mengestimasi model autoregressif linier, yaitu first difference GMM dan system GMM. Penelitian ini menggunakan modules pada Stata 13.1 yaitu modules XTABOND2. Prosedur analisis menggunakan GMM memerlukan beberapa uji untuk menspesifikasikan model agar dapat memberikan hasil yang valid 
dan konsisten yaitu model yang tidak terjadi korelasi serial pada eror dan instrumen yang digunakan secara keseluruhan pada model adalah valid. Pengujian pertama untuk menilai kelayakan dari model dengan melihat hasil nilai dari AR (1) dan AR (2) yang merupakan nilai pvalues untuk first dan second order autocorrelated disturbance. Test untuk AR (1) biasanya menolak hipotesis nol, tetapi indikator yang penting ditunjukkan oleh nilai dari AR (2). Uji selanjutnya adalah Sargan Test atau Hansen Test terhadap overidentifying restriction yang menguji validatas variabel instrumen yang digunakan secara keseluruhan dengan menguji sampel yang analog dengan control moment yang digunakan. Hipotesis nol dari uji ini adalah variabel instrument yang digunakan valid dan terdistribusi menurut chi square. dengan (J-K) derajat kebeba- san. J adalah jumlah variabel instrument dan K adalah jumlah variabel penjelas. Kelayakan model penelitian untuk mengestimasi model adalah apabila nilai probabilitas chi square mempunyai tingkat signifikasi lebih besar dari 0,1 atau 0,5 atau 0,01 maka menerima $\mathrm{H}_{0}$ atau dengan kata lain variabel instrument yang digunakan valid.

\section{HASIL DAN PEMBAHASAN}

Analisis awal untuk memberikan gambaran kondisi dari hubungan antar variabel. Berdasarkan hasil analisis korelasi pada tabel 2 ditunjukkan bahwa nilai positif dan signifikan ditunjukkan pada keseluruhan variabel tu $\ln s_{k i t}, \ln e_{i t}, \ln h_{i t}, \quad \ln \left(n_{i}+g+\delta\right)_{i t}, \quad$ dan $\ln g x_{i t}$ terhadap $\ln y_{i t}$ yang sesuai dengan harapan yang ditunjukkan terhadap hubungan antar variabel tersebut.

Tabel 2

Matriks Korelasi antar Variabel

\begin{tabular}{ccccccc}
\hline & $\ln y_{i t}$ & $\ln s_{k i t}$ & $\ln e_{i t}$ & $\ln h_{i t}$ & $\ln \left(n_{i}+g+\delta\right)_{i t}$ & $\ln g x_{i t}$ \\
\hline $\ln y_{i t}$ & 1.0000 & & & & \\
$\ln s_{k i t}$ & 0.3092 & 1.0000 & & & \\
& $(0.0000)$ & & & & \\
$\ln e_{i t}$ & 0.5949 & 0.1864 & 1.0000 & & \\
& $(0.0000)$ & $(0.0007)$ & & & \\
$\ln h_{i t}$ & 0.4478 & 0.1625 & 0.5377 & 1.0000 & & \\
& $(0.0000)$ & $(0.0033)$ & $(0.0000)$ & & & \\
$\ln \left(n_{i}+g+\delta\right)_{i t}$ & 0.0900 & -0.0784 & -0.0108 & -0.0827 & 1.0000 & \\
& $(0.0634)$ & $(0.1577)$ & $(0.8458)$ & $0.2024)$ & & \\
$\ln g x_{i t}$ & 0.6177 & 0.6383 & 0.4006 & 0.4432 & -0.0316 & 1.0000 \\
& $(0.0000)$ & $(0.0000)$ & $(0.0000)$ & $(0.0000)$ & $(0.5489)$ & \\
\hline
\end{tabular}

Keterangan: Angka dalam kurung adalah (p-value)

Nilai korelasi antara $\ln y_{i t}$ terhadap investasi $\left(\ln s_{k i t}\right)$ bernilai positif dan memiliki nilai korelasi sebesar 0.3092. Nilai korelasi antara $\ln y_{i t}$ terhadap pendidikan $\left(\ln e_{i t}\right.$ ) bernilai positif dan memiliki nilai korelasi sebesar 0.5949, sementara terhadap kesehatan $\left(h_{i t}\right)$ juga bernilai positif dan memiliki nilai korelasi sebesar 0.4478. Nilai korelasi antara $\ln y_{i t}$ terhadap pertumbuhan penduduk $\left(\ln \left(n_{i}+g+\delta\right)_{i t}\right)$ bernilai positif dan memiliki nilai korelasi sebesar 0.0900. Hal yang sama juga ditunjukkan pada hubungan $\ln y_{i t}$ terhadap pengeluaran pemerintah $\left(\ln g x_{i t}\right)$ bernilai positif dan memiliki nilai korelasi sebesar 0.6177. Secara keseluruhan ekspektasi kondisi dari hubungan antar variabel memberikan gambaran awal 
tentang kondisi yang diharapkan pada penelitian ini.

Analisis lanjutan pada model ini dibagi menjadi dua bagian. Pertama, hasil analisis estimasi model panel statis dengn pendekatan common effects (CE), random effect (RE), dan fixed effect (FE). Kedua, hasil analisis estimasi model panel dinamis dengan menggunakan generalized method of moments (GMM) yang dibagi menjadi difference GMM dan system GMM. Analisis hasil regresi pertama ditunjukkan pada tabel 4 . Hal pertama yang dilakukan adalah menguji model terbaik antara CE, RE dan FE. Berdasarkan hasil uji spesifikasi model nilai p-value untuk uji LM memberikan hasil signifikan yang berarti antara model CE dan RE model yang dipilih adalah RE. Pada uji kedua yaitu hausman test didapatkan nilai yang signifikan sehingga dapat disimpulkan bahwa modal FE lebih baik dibandingkan dengan model yang lain.
Berdasarkan hasil dari uji spesifikasi model menunjukkan bahwa model terbaik adalah FE, maka berdasarkan kolom fixed effect pada tabel 3 dapat dianalisis bahwa kontribusi modal manusia yaitu pendidikan $\left(\ln e_{i t}\right)$ dan kesehatan $\left(\ln h_{i t}\right)$ memiliki arah yang positif dan secara statistik signifikan pada level 1 persen. Hal lain yang dapat ditunjukkan dari analisis dengan model FE adalah kontribusi positif dari pertumbuhan penduduk yang secara statistik signifikan pada level 1 persen. Sementara itu, peran dari investasi fisik $\left(\ln s_{k i t}\right)$ dan pengeluaran pemerintah $\left(\ln g x_{i t}\right)$ tidak memiliki peran terhadap pertumbuhan ekonomi karena secara statistik tidak signifikan. Indikator lain yang dapat dijelaskan dari hal ini adalah terjadinya konvergensi pada model ini yang ditunjukkan pada nilai koefisien dari lag variabel PDRB per Kapita ( $\ln y_{i, t-\tau}$ ) yang secara statistik signifikan pada level 1 persen.

Tabel 3

Model Panel Statis

\begin{tabular}{clcl}
\hline VARIABLES & $\begin{array}{l}\text { Variabel Dependen }\left(\ln \mathbf{y}_{\mathbf{i}, \mathbf{t}}\right) \\
\text { Common Effect }\end{array}$ & Random Effect & Fixed Effect \\
\hline $\ln y_{i, t-\tau}$ & $0.984^{* * *}$ & $0.983^{* * *}$ & $0.868^{* * *}$ \\
& $(0.00451)$ & $(0.00512)$ & $(0.0235)$ \\
$\ln s_{\text {kit }}$ & 0.00106 & 0.000514 & -0.00213 \\
& $(0.00120)$ & $(0.00124)$ & $(0.00138)$ \\
$\ln e_{i t}$ & $0.0760^{* * *}$ & $0.0786^{* * *}$ & $0.297^{* * *}$ \\
& $(0.0221)$ & $(0.0252)$ & $(0.0895)$ \\
$\ln h_{i t}$ & 0.0974 & 0.112 & $1.155^{* * *}$ \\
& $(0.0596)$ & $(0.0698)$ & $(0.321)$ \\
$\ln \left(n_{i}+g+\delta\right)_{i t}$ & 0.00763 & $0.0140^{* *}$ & $0.0262^{* * *}$ \\
& $(0.00702)$ & $(0.00704)$ & $(0.00707)$ \\
$\ln g x_{i t}$ & -0.00181 & -0.00119 & -0.00849 \\
Constant & $(0.00297)$ & $(0.00321)$ & $(0.00926)$ \\
& -0.353 & -0.401 & $-4.188^{* * *}$ \\
LM Test & $(0.225)$ & $(0.265)$ & $(1.254)$ \\
Prob $>$ chibar2 & 18.88 & & \\
Hausman Test & 0.000 & & \\
\hline
\end{tabular}




\begin{tabular}{llcc}
\hline VARIABLES & $\begin{array}{l}\text { Variabel Dependen }\left(\ln \mathbf{y}_{\mathbf{i}, \mathbf{t}}\right) \\
\text { Common Effect }\end{array}$ & Random Effect & Fixed Effect \\
\hline Prob>chi2 & 4.14 & 0.000 & \\
F- Tests & 0.000 & & \\
Prob-F & 326 & 326 & 326 \\
Obs. & 0.996 & & 0.958 \\
R-squared & & 33 & 33 \\
Jumlah Prov. & & & \\
\hline
\end{tabular}

Angka dalam kurung adalah standar eror, tanda ${ }^{* * *} \mathrm{p}<0.01,{ }^{* *} \mathrm{p}<0.05,{ }^{*} \mathrm{p}<0.1$. Nilai

koefisien $\ln y_{i, t-\tau}$ yaitu $\eta_{i}$ memiliki nilai $\left(1-\beta_{i}\right)$

Berdasarkan penjelasan diatas bahwa model panel data pada pertumbuhan ekonomi merupakan model dinamis dimana terdapat nilai lag dependen variabel pada sisi sebelah kanan. Secara teoritis hal tersebut mengakibatkan kondisi yang bias jika tidak menggunakan alat analisis yang tepat. Penelitian ini mengembangkan hal tersebut dengan menggunakan Generalized Method of Moments (GMM) untuk mengatasi permasalahan yang muncul karena kondisi model pertumbuhan ekonomi yang dinamis. Hasil dari regresi menggunakan model GMM ditunjukkan pada tabel 4. Pada tabel 4 ditunjukkan beberapa spesifikasi model untuk mendapatkan model terbaik yang dapat merepresentasikan hasil yang terbaik dalam model. Pada model GMM ditunjukkan model 1, 2, dan 3 yang merupakan identifikasi pada kondisi model. Pada model 1 kondisi yang dilakukan yaitu dengan mengasumsikan bahwa keseluruhan independen variabel endogen kecuali tingkat pertumbuhan populasi sehingga harus diinstrumentasi sesuai dengan kondisi pada analisis GMM. Model 2 mengasumsikan bahwa variabel lag variabel PDRB per kapita, Investasi fisik, modal manusia untuk pendidikan dan kesehatan dan pendidikan diasumsikan endogen sehingga harus diinstrumentasi sesuai dengan kondisi pada analisis GMM. Model 3 mengasumsikan bahwa hanya variabel lag variabel PDRB per kapita dan modal manusia untuk pendidikan dan kesehatan dan pendidikan yang diasumsikan en- dogen sehingga harus diinstrumentasi sesuai dengan kondisi pada analisis GMM.

Sebelum melakukan intepretasi hasil estimasi pada model GMM, hal pertama yang harus dilakukan adalah menguji kelayakan dari model GMM. Pengujian kelayakan model GMM dilakukan untuk mendapatkan model yang valid yaitu model yang tidak terjadi korelasi serial pada eror dan instrumen yang digunakan secara keseluruhan pada model adalah valid. Pengujian pertama untuk menilai kelayakan dari model dengan melihat hasil nilai dari AR (1) dan AR (2) yang merupakan nilai $\mathrm{p}$-values untuk first dan second order autocorrelated disturbance. Test untuk AR (1) biasanya menolak hipotesis nol, tetapi indikator yang penting ditunjukkan oleh nilai dari AR (2). Berdasarkan output pada tabel 5 ditunjukkan bahwa nilai p-value dari AR (1) menunjukkan nilai yang signifikan tetapi fokus analisis berada pada AR (2), nilai AR (2) pada model difference GMM model $1 p$-value 0.0064 , model 2 nilai $p$-value 0.0058 , dan model 3 nilai $p$-value 0.0053 . Berdasarkan hasil tersebut keseluruhan model difference GMM memiliki nilai $p$-value dibawah nilai alpha 5 persen maka dapat disimpulkan bahwa pada model difference GMM terjadi serial autokorelasi pada eror. Sementara itu pada model system GMM dapat ditunjukkan bahwa nilai $p$-value dari AR (1), sementara itu nilai AR (2) pada model 1 nilai $p$-value 0.083 , model 2 nilai $p$-value 0.022 , dan model 3 nilai $p$-value 0.0091. Berdasarkan hasil tersebut model 2 dan 3 pada system GMM mem- 
iliki nilai $p$-value dibawah nilai alpha 5 persen maka dapat disimpulkan bahwa pada model terjadi serial autokorelasi pada eror. Nilai AR (2) pada model 1 menunjukkan nilai $p$-value diatas nilai alpha 5 persen sehingga dapat disimpulkan untuk model 1 system GMM tidak terjadi serial autokorelasi pada eror.

Uji kelayakan model yang kedua yaitu untuk menguji validitas dari instrumen yang digunakan dalam model. Hasil output untuk sargan test pada model difference GMM menunjukkan bahwa pada model 1 nilai $p$-value 0.973 , model 2 nilai $p$-value 0.714 , dan model 3 nilai $p$-value 0.0545 . Berdasarkan hasil tersebut dapat disimpulakan bahwa instrumen yang digunakan pada model untuk keseluruhan model difference GMM valid. Pada model system GMM nilai sargan test untuk model 1 nilai $p$-value 0.997, model 2 nilai $p$ value 0.953 , dan model 3 nilai $p$-value 0.269 . Ber- dasarkan hasil tersebut dapat disimpulkan bahwa instrumen yang digunakan pada model untuk keseluruhan model system GMM valid.

Berdasarkan uji kelayakan model maka model yang dapat diinterpretasikan adalah model yang tidak terjadi autokorelasi serial pada eror dan memiliki instrumen yang valid. Disimpulkan bahwa kondisi dari keseluruhan model difference GMM tidak layak karena terjadi serial autokorelasi pada eror walaupun instrument yang digunakan valid. Sementara itu, untuk model system GMM ditunjukkan bahwa pada model 2 dan 3 tidak layak karena terjadi serial autokorelasi pada eror walaupun instrument yang digunakan valid. Model terbaik pada penelitian ini ditunjukkan pada model 1 untuk system GMM dimana tidak terjadi autokorelasi serial pada eror dan memiliki instrumen yang valid.

Tabel 4

Model Panel Dinamis

\begin{tabular}{|c|c|c|c|c|c|c|}
\hline \multirow{3}{*}{ VARIABLES } & \multicolumn{6}{|c|}{ Variabel Dependen $\left(\ln y_{i, t}\right)$} \\
\hline & \multicolumn{3}{|c|}{ Difference GMM } & \multicolumn{3}{|c|}{ System GMM } \\
\hline & (1) & (2) & (3) & (1) & (2) & (3) \\
\hline \multirow[t]{2}{*}{$\ln y_{i, t-\tau}$} & $0.885^{* * *}$ & $0.881^{* * *}$ & $0.885^{\star * *}$ & $0.984^{* * *}$ & $0.984^{* * *}$ & $0.979^{* * *}$ \\
\hline & $(0.0303)$ & $(0.0317)$ & $(0.0324)$ & $(0.00499)$ & $(0.00530)$ & $(0.00626)$ \\
\hline \multirow[t]{2}{*}{$\ln s_{k i t}$} & $-0.00312^{*}$ & $-0.00337^{*}$ & $-0.00436^{* *}$ & 0.000986 & 0.00107 & 0.000263 \\
\hline & $(0.00177)$ & $(0.00180)$ & $(0.00189)$ & $(0.00134)$ & $(0.00146)$ & $(0.00145)$ \\
\hline \multirow{2}{*}{$\ln e_{i t}$} & $0.310^{* * *}$ & $0.351^{* * *}$ & $0.426^{* * *}$ & $0.0716^{* * *}$ & $0.0851^{* * *}$ & $0.120^{* * *}$ \\
\hline & $(0.113)$ & $(0.121)$ & $(0.135)$ & $(0.0248)$ & $(0.0265)$ & $(0.0320)$ \\
\hline \multirow[t]{2}{*}{$\ln h_{i t}$} & $1.243^{* * *}$ & $1.264^{* *}$ & $1.306^{* *}$ & $0.127^{*}$ & 0.120 & 0.138 \\
\hline & $(0.477)$ & $(0.507)$ & $(0.522)$ & $(0.0740)$ & $(0.0801)$ & $(0.0917)$ \\
\hline \multirow[t]{2}{*}{$\ln \left(n_{i}+g+\delta\right)_{i t}$} & $0.0220^{* * *}$ & $0.0219^{* * *}$ & $0.0204^{* *}$ & 0.00788 & 0.00874 & 0.0102 \\
\hline & $(0.00813)$ & $(0.00816)$ & $(0.00827)$ & $(0.00775)$ & $(0.00786)$ & $(0.00785)$ \\
\hline \multirow[t]{2}{*}{$\ln g x_{i t}$} & -0.0119 & -0.0147 & -0.0213 & -0.00180 & -0.00234 & -0.00160 \\
\hline & $(0.0124)$ & $(0.0130)$ & (0.0137) & $(0.00331)$ & $(0.00342)$ & $(0.00342)$ \\
\hline \multirow[t]{2}{*}{ Constant } & & & & $-0.469^{*}$ & -0.462 & $-0.574^{*}$ \\
\hline & & & & $(0.281)$ & $(0.303)$ & $(0.341)$ \\
\hline Obs. & 285 & 285 & 285 & 326 & 326 & 326 \\
\hline Jumlah Prov. & 32 & 32 & 32 & 33 & 33 & 33 \\
\hline
\end{tabular}




\begin{tabular}{cccc|ccc}
\hline \multirow{2}{*}{ VARIABLES } & \multicolumn{7}{c}{ Variabel Dependen (ln $\mathbf{y}_{\mathbf{i}, \mathbf{t}}$ ) } \\
\cline { 2 - 7 } & \multicolumn{7}{c}{ Difference GMM } & \multicolumn{3}{c}{ System GMM } \\
\cline { 2 - 7 } & $\mathbf{( 1 )}$ & $\mathbf{( 2 )}$ & $\mathbf{( 3 )}$ & $\mathbf{( 1 )}$ & $\mathbf{( 2 )}$ & $\mathbf{( 3 )}$ \\
\hline Sargan Test & 186.1 & 185.4 & 176.6 & 208.9 & 201.7 & 189.2 \\
P-Value & 0.973 & 0.714 & 0.0545 & 0.997 & 0.953 & 0.269 \\
AR (1) & -8.177 & -8.186 & -8.112 & -5.204 & -6.350 & -7.542 \\
P-Value & 0.00 & 0.00 & 0.00 & 0.00 & 0.00 & 0.00 \\
AR (2) & 2.727 & 2.758 & 2.791 & 1.724 & 2.299 & 2.610 \\
P-Value & 0.00639 & 0.00581 & 0.00526 & 0.0847 & 0.0215 & 0.00906 \\
Instrumen & 231 & 203 & 154 & 276 & 244 & 185 \\
\hline
\end{tabular}

Angka dalam kurung adalah standar eror, tanda ${ }^{* *} \mathrm{p}<0.01,{ }^{* *} \mathrm{p}<0.05,{ }^{*} \mathrm{p}<0.1$. Nilai koefisien $\ln y_{i, t-\tau}$ yaitu $\eta_{i}$ memiliki nilai $\left(1-\beta_{i}\right)$

Hasil output estimasi model 1 untuk system GMM digunakan sebagai analisis karena kondisinya yang sesuai dengan kelayakan model. Hal utama yang menjadi fokus kajian penelitian ini adalah kontribusi dari modal manusia yaitu pendidikan dan kesehatan terhadap pertumbuhan ekonomi. Berdasarkan hasil dari output dapat dianalisis bahwa nilai koefisien dari pendidikan $\left(\ln e_{i t}\right)$ memiliki nilai positif sebesar 0.0851 dan signifikan pada level 1 persen. Kondisi yang sama terjadi pada nilai koefisien kesehatan $\left(\ln h_{i t}\right)$ dimana memiliki nilai positif sebesar 0.127 dan signifikan pada level 10 persen. Berdasarkan hasil tersebut maka secara empiris dapat dibuktikan tentang peran penting dari modal manusia yaitu pendidikan dan kesehatan terhadap pertumbuhan ekonomi di Indonesia. Hal ini sejalan dengan penelitian sebelumnya yang dilakukan oleh (Knowles \& Owen, 1995) untuk analisis antar negara, (Li \& Liang, 2010) antar negara di Asia Timur, dan (Li \& Huang, 2009) untuk provinsi di China. Temuan yang sejalan dengan penelitian ini di Indonesia (Kharisma \& Saleh, 2013) hanya menunjukkan peran dari pendidikan terhadap pertumbuhan ekonomi sementara kesehatan secara statistik tidak signifikan.

Hal lain yang dapat dijelaskan dari hasil output tersebut adalah kontribusi sektor fisik dan peran pemerintah yaitu investasi fisik $\left(\ln s_{\text {kit }}\right)$, pertumbuhan penduduk, dan pengeluaran pemerintah $\left(\ln g x_{i t}\right)$ yang memiliki nilai ecara statistik tidak signifikan. Hal ini memberikan gambaran bahwa kontribusi sektor fisik tidak terlalu menjadi sesuatu yang dominan untuk pertumbuhan ekonomi yang lebih baik justru kontribusi sektor non-fisik seperti modal manusia akan memberikan nilai yang lebih baik. Di sisi lain peran pemerintah melalui pendanaan pembangunan cenderung belum mampu untuk memberikan kontribusi. Kecenderungan aktifitas pemerintah yang menggunakan alokasi dana untuk aktifitas rutin menjadi salah satu hal yang terjadi, seharusnya pemerintah mampu untuk mendukung pertumbuhan ekonomi dengan alokasi dana yang terorientasi pada sektor yang berimplikasi terhadap pembangunan ekonomi.

Konvergensi yang menjadi salah satu indikator dan merupakan efek lanjutan dari pertumbuhan ekonomi terjadi pada provinsi-provinsi di Indonesia. Hal tersebut ditunjukkan dari nilai lag PDRB per kapita $\left(\ln y_{i, t-\tau}\right)$ yang memiliki nilai kurang dari 1 yaitu 0.984 dan secara statistik signifikan pada level 1 persen. Hal ini membuktikan hipotesis konvergensi kondisional dimana daerah yang memiliki tingkat pertumbuhan awal yang rendah dapat mengakumulasi proses pertumbuhannya dan mempu untuk mengejar daerah yang awalnya maju. Implikasinya adalah daerah yang maju akan memiliki kecepatan konvergensi 
sebesar 1.613 persen dan daerah yang pertumbuhan awalnya rendah akan dapat mengejar separo dari kondisinya tersebut dalam waktu 42.97 tahun. Kontribusi positif dari pendidikan dan kesehatan dalam model konvergensi kondisional tersebut juga memiliki implikasi bahwa faktor yang mampu untuk meningkatkan akselerasi pertumbuhan ekonomi tersebut terdapat pada pendidikan dan kesehatan. Hal ini sejalan dengan penelitian sebelumnya yaitu (Firdaus \& Yusop, 2009) dan (Kharisma \& Saleh, 2013) yang juga menemukan hal yang sama terhadap terbuktinya hipotesis konvergensi pada provinsi di Indonesia.

\section{SIMPULAN}

Kontribusi modal manusia sebagai penentu pertumbuhan pada level provinsi di Indonesia secara empiris terbukti. Hal tersebut ditunjukkan oleh nilai positif variabel pendidikan dan kesehatan. Indikasi ini menunjukkan bahwa peran sentral modal manusia menurut teori pertumbuhan endogen terbukti di Indonesia. Hal ini seharusnya menjadi perhatian bagi pengambil kebijakan untuk meningkatkan investasi pada sektor pendidikan dan kesehatan sehingga mampu untuk meningkatkan pembangunan ekonomi di Indonesia.

Terjadinya konvergensi kondisional secara empiris terbukti pada level provinsi di Indonesia. Hal ini memberikan gambaran bahwa daerahdaerah yang dianggap sebagai daerah yang awalnya memiliki kondisi pertumbuhan rendah dapat mengakselerasi pertumbuhan ekonominya sehingga mampu untuk mengejar daerah-daerah yang awalnya maju. Kontribusi dari pendidikan dan kesehatan dalam kondisi konvergensi secara positif berperan, yang berarti pendidikan dan kesehatan menjadi faktor utama penurunan tingkat ketimpangan pembangunan ekonomi antar daerah.

\section{DAFTAR PUSTAKA}

Aka, B. F., \& Dumon, J. C. (2008). Health, Education and Economic Growth: Testing for Long- Run Relationships and Causal Links. Applied Econometrics and International Development Development, 8(2), 101-113.

Barro, R. J. (1992). Human Capital and Economic Growth. Proceedings, Federal Reserve Bank of Kansas City, (1966), 199-230. http://doi.org/10.1086/449834

Barro, R. J. (2013). Health and Economic Growth. Annals of Economics and Finance, 14(2), 305-342. http://doi.org/10.1016/S15740684(05)01006-3

Becker, G. S. (2006). The Age of Human Capital. In H. Lauder, P. Brown, J.-A. Dillabough, \& A. H. Halsey (Eds.), Education, Globalization and Social Change (1st ed., pp. 292-294). Oxford: Oxford University Press.

Benhabib, J., \& Spiegel, M. M. (1994). The Role of Human Capital in Economic Development Evidence from Aggregate Cross-Country Data. Journal of Monetary Economics, 34(2), 143-173. http://doi.org/10.1016/03043932(94)90047-7

Bloom, D. E., Canning, D., \& Sevilla, J. (2004). The effect of health on economic growth: A production function approach. World Development, 32(1), 1-13. http://doi.org/10.1016/j.worlddev.2003.0 7.002

Bond, S. R., Hoeffler, A., \& Temple, J. (2001). GMM Estimation of Empirical Growth Models. Economics Papers, Economics Group, Nuffield College: University of Oxford.

Caselli, F., Esquivel, G., \& Lefort, F. (1996). Reopening the Convergence Debate: A New Look at Cross-Country Growth 
Empirics. Journal of Economic Growth, 1(3), 363-389.

Firdaus, M., \& Yusop, Z. (2009). Dynamic analysis of regional convergence in Indonesia. International Journal of Economics and Management, 3(1), 73-86.

Hanushek, E. A. (2013). Economic growth in developing countries: The role of human capital. Economics of Education Review, 37, 204-212.

http://doi.org/10.1016/j.econedurev.201 3.04 .005

Hanushek, E. A., \& Kimko, D. D. (2000). Schooling, Labor Force Quality, and the Growth of Nations. American Economic Review, 90(5), 1184-1208. http://doi.org/10.1257/aer.90.5.1184

Islam, N. (1995). Growth Empirics : A Panel Data Approach. The Quarterly Journal of Economics, Oxford University, 110(4), 1127$1170 . \quad$ Retrieved from http://www.jstor.org/stable/2946651

Kharisma, B., \& Saleh, S. (2013). Convergence of Income Among Provinces in Indonesia 1984-2008: A Panel Data Approach. Journal of Indonesian Economy and Business, 28(2), 167-187.

Knowles, S., \& Owen, P. D. (1995). Health Capital and Cross-Country Variation in Income per Capita in The Mankiw-Romer-Weil Model. Economics Letters, 48, 99-106.

Li, H., \& Huang, L. (2009). Health, education, and economic growth in China: Empirical findings and implications. China Economic Review, 20(3), 374-387. http://doi.org/10.1016/j.chieco.2008.05.0 01

Li, H., \& Liang, H. (2010). Health, Education, and Economic Growth in East Asia. Journal of Chinese Economic and Foreign Trade Studies, $8(2)$, 110-131. http://doi.org/10.1108/105692112112044
92

Lucas, R. E. (1988). On the mechanics of economic development. Journal of Monetary Economics, 22(1), 3-42. http:/ / doi.org/10.1016/03043932(88)90168-7

Mankiw, N. G., Romer, D., \& Weil, D. N. (1992). A Contribution to the Empirics of Economic Growth. The Quarterly Journal of Economics, Oxford University, 107(2), 407-437. http:/ / doi.org/10.3386/w19870

Pritchett, L. (2001). Where Has All the Education Gone? The World Bank Economic Review, 15(3), 367-391.

Romer, P. M. (1990). Human Capital And Growth: Theory and Evidence. Carnegie-Rochester Conference Series on Public Policy, 32, 251$286 . \quad$ http:// doi.org/10.1016/01672231(90)90028-J

Ross, L., \& Renelt, D. (1992). A Sensitivity Analysis Of Cross Country Growth Regressions. American Economic Review, 82(4), 942-963.

Schultz, T. W. (1961). Investment in Human Capital. The American Economic Review, 51(1), 1-17. 